\title{
City-wide Quality Assessment of Sandcrete Masonry Blocks Produced in Lagos, Ibadan and Abeokuta Metropolitan-cities in South-western Nigeria
}

\author{
*Osagie Ibhadode, ${ }^{1}$ S. A. B. Fiyebo, ${ }^{2}$ C. C. Egege $^{3}$ and M. C. Ugonna ${ }^{3}$ \\ Research Engineer ${ }^{1}$, Research Officer ${ }^{2}$, Research Officer ${ }^{3}$ \\ Building Research Department ${ }^{1,3}$ \\ Engineering Materials Research Department ${ }^{2}$ \\ Nigerian Building and Road Research Institute (NBRRI) \\ [Federal Ministry of Science and Technology, Abuja] \\ Nigeria
}

\begin{abstract}
In this research work, a total of nine thousand (9,000) numbers of 6 inches (150 mm)-thick Sandcrete masonry blocks and another total of nine thousand (9,000) numbers of 9 inches (225 mm)-thick Sandcrete masonry blocks were collected as Testsamples from three hundred (300) Sandcrete block-making factories, which are randomly sited in thirty (30) rapidly developing towns/localities located within three (3) highly-populated and state-capital metropolitan-cities-i.e. 'Lagos', 'Ibadan' and 'Abeokuta' in South-Western Nigeria. Thus, from the cumulative total number of eighteen thousand $(18,000)$ Sandcrete block testsamples, each of the thirty (30) numbers of ' 6 inch-thick block test-samples' and each of the thirty (30) numbers of ' 9 inch-thick block test-samples' which were collected from each of the ten (10) Block-making factories per town/locality was subjected to two (2) critical quality-evaluation tests-i.e. Compressive-strength $\left(f_{\text {block }}\right)$ test [using a compression-testing machine] and Water absorption coefficient $\left(W_{A C}\right)$ test [in accordance with standard established procedures and then, the mean values were computed and adopted as the representative/characteristic data for each Block-making factory. Consequently, the obtained results/data were then comparatively analysed using the Standards Organization of Nigeria 'SON'NIS 87: 2007 standard specified (recommended) values to empirically evaluate the Block-making/production quality of each of town/locality per city and of each city. Amongst other things, the comparative analysis of the obtained results/data showed that: while all (100\%) of the tested Sandcrete masonry blocks produced in Lagos city and Ibadan city are classified as substandard-having failed to meet (fulfil) the NIS 87: 2007 standard requirements; just 30\% of the 6"-thick Sandcrete masonry blocks, and as much as 50\% of the 9"-thick Sandcrete masonry blocks produced in Abeokuta city are classified as standard-having successfully met (satisfied) the NIS 87: 2007 Standard requirements—-thus, making them the most ideal for construction purposes.
\end{abstract}

Key Words: Sandcrete block, Compressive-strength, Water-absorption coefficient, NIS, Nigeria, Lagos.

\section{INTRODUCTION}

Presently, in some West-African countries such as Nigeria, Benin, Togo and Ghana; a careful examination of most building structures in many cities and towns, clearly shows that, the largest percentage of the buildings' walling materials consist of 'Sandcrete' - in the form of Sandcrete blocks. However, this might only be evident to the inquisitive mind, whose curiosity leads him/her to realize that, beneath all of the exterior and interior wall-finishes [such as mortar, paints and tiles] of most buildings, there lies the overwhelming dominance of Sandcrete blocks - as a walling material over Concrete - the latter which is used as a material for casting lintels and primary load-bearing structural members/elements i.e. slabs, beams and columns; in terms of the relative quantities used for the construction of buildings. More so, Sandcrete block is relatively cheaper (more affordable) than 
other alternatives as a walling material for building construction in most developing countries with high housing deficit indices.

While Concrete is summarily a man-made composite construction material consisting of mixed batches of fillers (fine aggregates \& coarse aggregates) which are placed within the surrounding binder-paste (cement, water \& air); under conditions that allow for ease of movement, curing and setting from its original plastic state to its final hardened state [1], [2]. Sandcrete on the other hand, is simply a yellowish-whitish material used for building, which is produced from a cementitious binder-[usually Portland cement] and natural sand in a circa ratio of 1:8, with the addition of water-being the single most-utilized/consumed material worldwide [3], which may be sourced directly or indirectly from the nearby natural water sources like rivers [4]. More often than not, Sandcrete in the form of a rectangular block - [which could be hollow or solid], is used in a very similar way as concrete masonry units to erect the walls of buildings [5].

Blocks are basically building units, which are larger than bricks and are used for the erection of the walls and partitions in buildings. Usually, they are produced to certain specifications, weights and dimensions that allow for ease of handling by the mason [6]. The BSI 6073:1981 opines that blocks are masonry units, whose dimension (L, W, H) exceed those of bricks, but do not necessarily exceed $0.65 \mathrm{~m}$, nor should its length or six times its thickness be lesser than its vertical height [7].

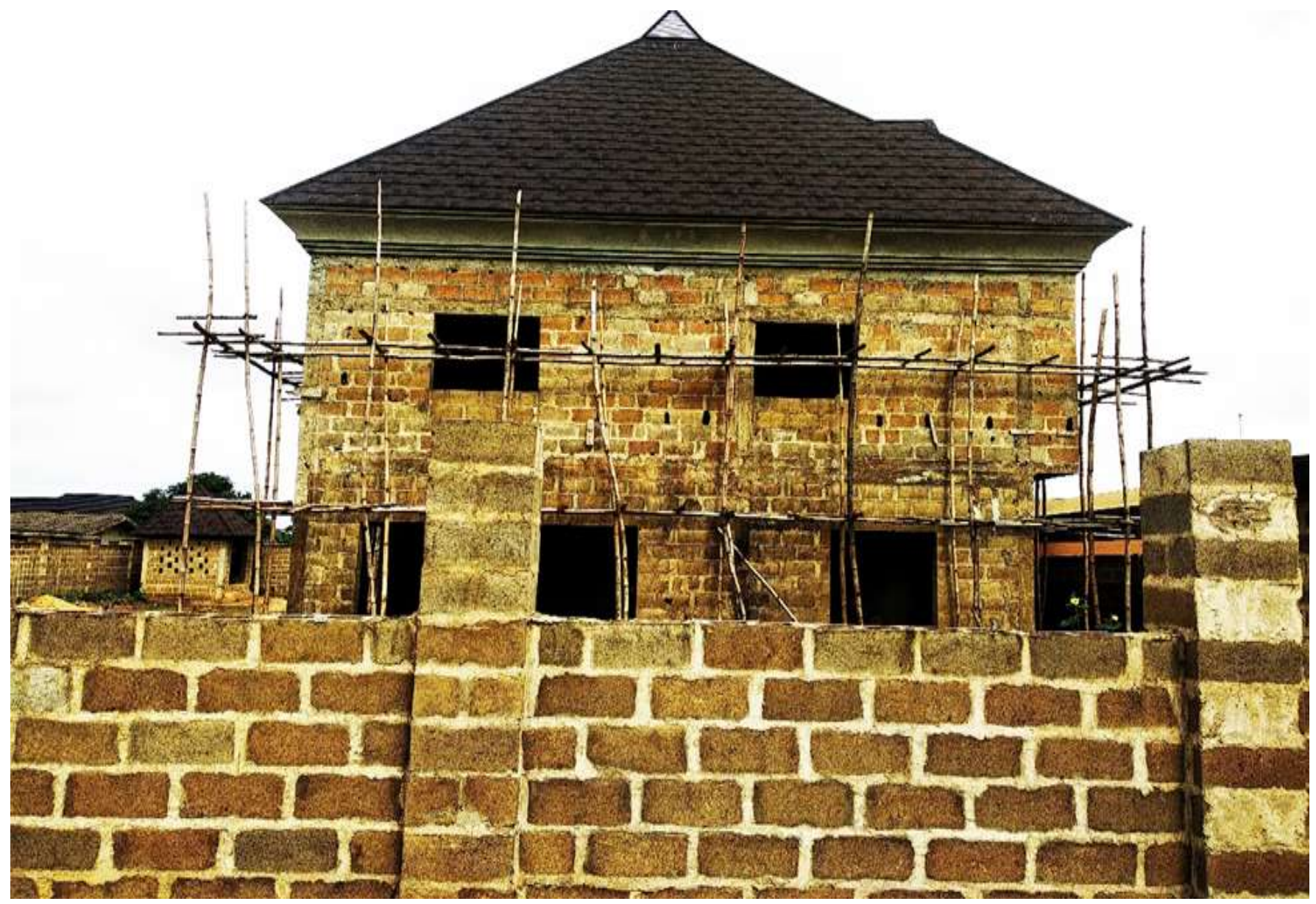

Figure 1: A Building and its Perimeter-fence under construction with the use of Sandcrete masonry blocks as the dominant wallingmaterial

As was earlier mentioned, sandcrete blocks are by far the most widely used types of blocks for building construction in Nigeria and in neighbouring Ghana [8], as could be seen in Figures 1-7. In specific terms, [9] noted that of all the physical infrastructures currently available in Nigeria, an estimated $90+\%$ were constructed using sandcrete blocks [7]. Obviously, this makes 'Sandcrete Block' a very important building material, which ranks at par with 'Concrete' and 'Mortar' in terms of usage in these countries.

A Sandcrete block is essentially a composite building/construction material that consists of cement, sand and water which is usually moulded into various sizes and shapes [10], [11], [12], [13]. There are two common variants (forms) of sandcrete block'Hollow Sandcrete Block' and 'Solid Sandcrete Block'. A hollow sandcrete block is often distinguished from a solid sandcrete block with the presence of a number of symmetric hollow openings which make them lighter and consequently cheaper to produce, only in terms of material cost, since the labour cost of producing both variants are basically the same. 
Specifically, rectangular-shaped hollow sandcrete blocks consist of a mixture of cement (binder) and sand (fine aggregate) at a mix ratio of 1:8 respectively, with the addition of a variable amount of water, in order to achieve the recommended compressivestrength [13], [14], [15], [16], [17]. However, [18] are of the opinion that, Sandcrete comprises of cement and sand mixed at a ratio of $1: 6$, which is then moistened by adding water and dried naturally on exposure to air.

Although, the utilization and/or conversion of waste materials [such as waste-plastic and waste-glass] to useful construction materials such as concrete [19] and ceramic tile [20] etc., is sometimes encouraged; most construction-industry experts would often prefer the use of carefully designed and batched quantities of ingredients-including aggregates, cement and water to produce concrete and some other construction materials such as Sandcrete masonry blocks with the desired properties [21].

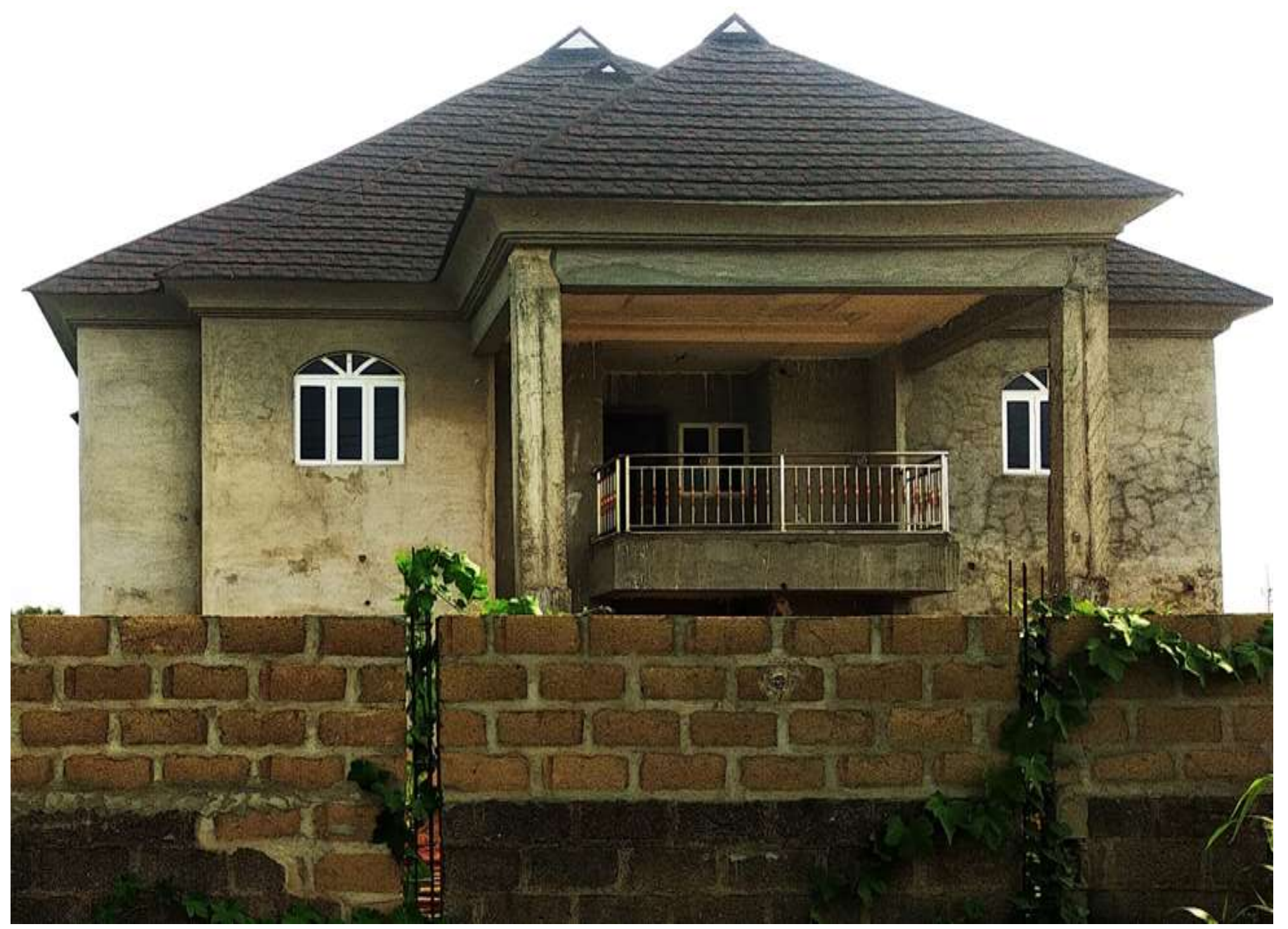

Figure 2: A Building and its Perimeter-fence constructed with Sandcrete masonry blocks as the major walling-material. However, while the Perimeter-fence is un-plastered, the Building is plastered with mortar as an exterior wall finishing-material.

The need to continuously study the effect(s) of minor and major variations in the 1:8 circa ratio and other constituents \& their relative proportions in sandcrete blocks, has become critically important in many fields of engineering such as Noise (Sound) damping and Wireless telecommunication network (GSM) pathloss investigation in buildings. This is in view of the negative effects of exposure to hazardous Noise-levels from various sources including electricity generators, machineries and aerial vehicular systems [22], [23], [24], [25], [26]; and the usual/regular telecommunication network-improvement projects and activities [27], [28], [29], [30], [31], [32].

Also, as is the case in many developing countries, the construction industry in Nigeria is facing several problems including quackery, corruption [33] and relatively high casualty \& fatality rates [such as building collapse occurrences/cases] during construction [34]. Also, in many African countries like Nigeria, the regulators and stakeholders in the construction sector are presently faced with the several challenges including the erection of sandcrete block buildings in unplanned or poorly planned settlements [35], and many of which are annually affected by devastating floods [36].

Furthermore, it is important to mention that, during the construction of a building with/without the use of sandcrete blocks [as the walling material], after the Structural-integrity evaluation — which is primarily considered, some other of issues of concern which 
are secondarily considered include Fire-resistance [37], [38] Safety \& Ergonomics [39], [40], [41]; Natural illumination [42] and Thermal comfort/Ventilation [43] — which aside the relatively high amount of electric power required to electrify high-electricload household devices/appliances like water pumps, heaters, pressing-irons and refrigerators/freezers [44], [45]; will certainly help to reduce the overall electrical energy consumption of a building, particularly in highly populated (a 2019 estimate: > 200 million persons) and developing African country like Nigeria where constant supply of the yet inadequate electric-power generated still eludes the populace nearly six decades after independence from British imperialism [22], [25], [23], [46], [47], [48].

In accordance with the ISO 8402:1986 standard, "the quality of a product or service is the sum total of its features and characteristics, that has the capability to meet the specified or suggested requirements [7]. Also, [18] and [49] simply explained that, the quality of a product or service, as its "fitness or purpose" or its "compliance with specification" [7]. More specifically, with respect to Sandcrete blocks, [50] stated that, there are a number of factors that eventually affect the overall quality of a Sandcrete block, which include the production process/conditions, dimension \& form, properties \& batching of constituents and the curing age/condition(s) etc. [7] characterized the compressive-strength of Sandcrete blocks produced in Ondo State, Nigeria.

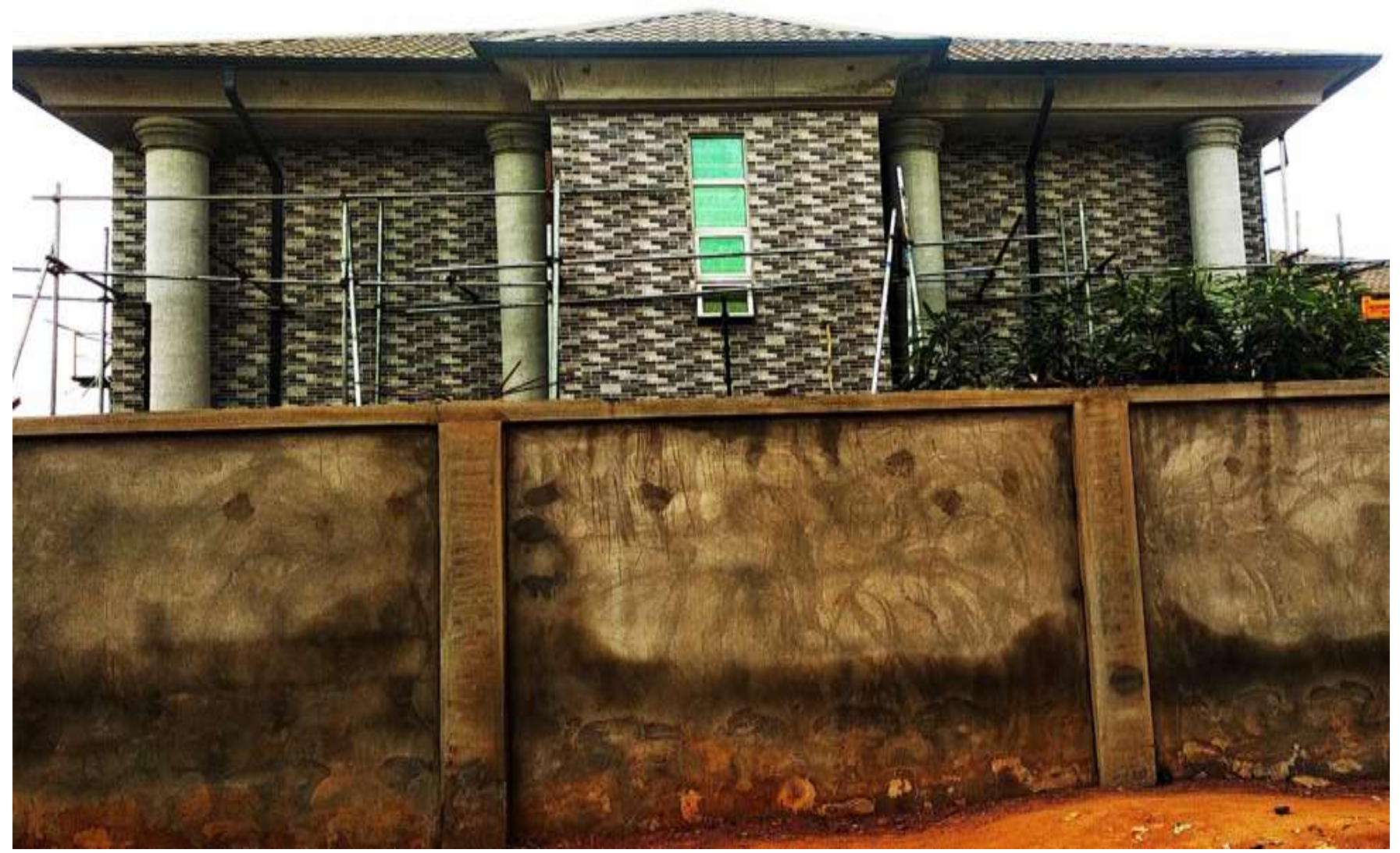

Figure 3: A Building and its Perimeter-fence constructed with Sandcrete masonry blocks as the major walling-material. However, while the Perimeter-fence is only plastered with mortar, Ceramic tile is used for the exterior finishing of the Building

Based on the findings of [51], it might be right to assert that, from Nigeria's pre-independence era up until the end of year 2000, Sandcrete blocks were being produced in the country with no clearly defined consideration to make them highly qualitative and/or specifically suitable for the country's building and environmental requirements/needs [7]. But, at the beginning of the $21^{\text {st }}$ century, the Standards Organization of Nigeria ( $\mathrm{SON}$ ) rose to the challenge, by issuing a set of benchmark quality specifications and applications for Sandcrete blocks - in which it was stated that "the minimum compressive-strength of Sandcrete blocks in Nigeria should be $2.5 \mathrm{~N} / \mathrm{mm}^{2}$ "; which was later reviewed in year 2004 and most recently in year 2007, to range from $2.50 \mathrm{~N} / \mathrm{mm}^{2}$ to $3.5 \mathrm{~N} / \mathrm{mm}^{2}$ for 6"-thick (150 mm-thick) Sandcrete blocks and 9"-thick (225 mm-thick) Sandcrete blocks respectively [13].

At this juncture, it is worth mentioning that, several researchers including [6], [49], [12], [20], [52], [17], [53], [54], [55], [56] and [57] have measured the compressive-strengths of sandcrete blocks produced in some localities in Nigeria. From which it was observed that, there were comparatively few cases of compliance with the NIS 87: 2007 standard requirements. 


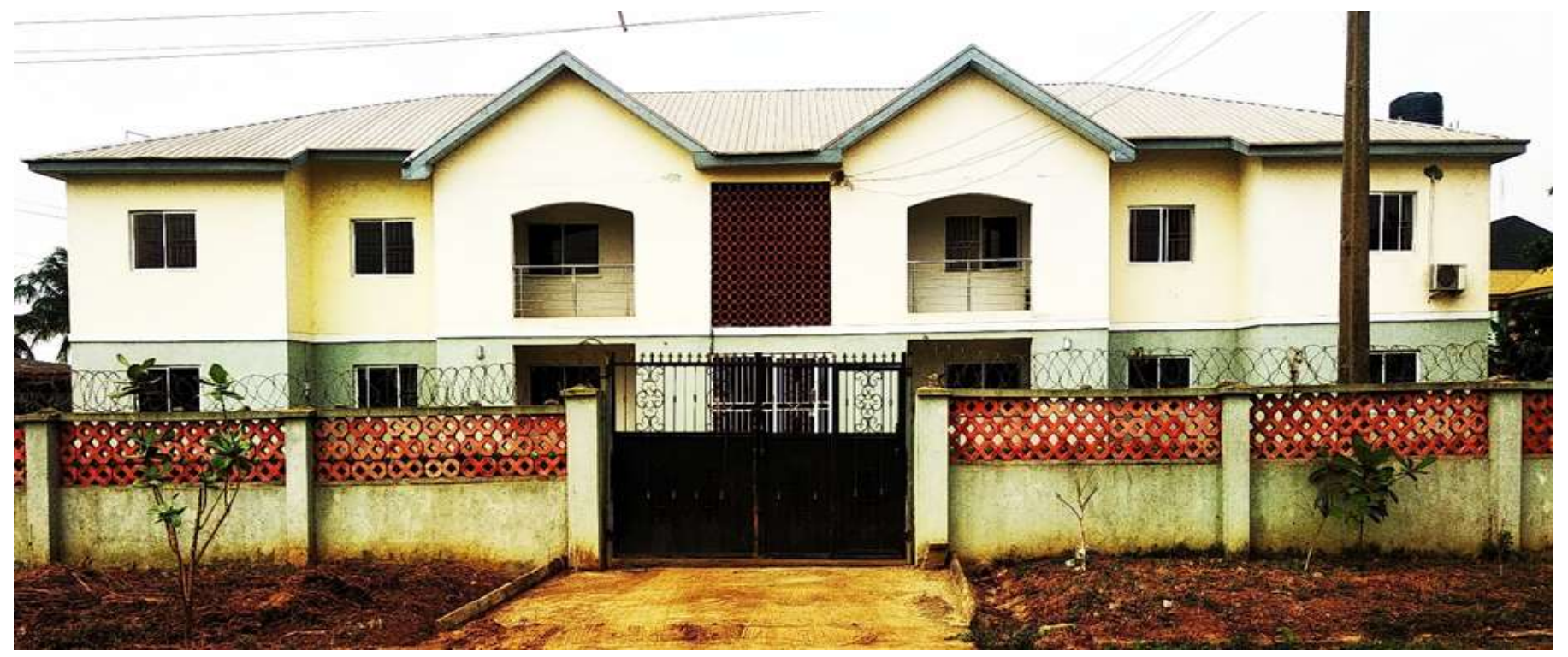

Figure 4: A Building and its Perimeter-fence constructed with Sandcrete masonry blocks and plastered with mortar. In addition, the exterior finishing material of both the building and Perimeter-fence is paint; and the top courses of the Perimeter-fence are constructed with fired-bricks hollow fancy-blocks

It may be noticed that most of the previous researchers seemed to have restricted their studies to cover just a single locality/town or city within a state in the country. However, this particular study which cuts across three states [Lagos, Oyo and Ogun] provides a much broader study-area, which simultaneously covers a total of thirty (30) towns/localities located within three (3) highlypopulated, economically-viable and oldest metropolitan-cities in the South-western geo-political zone of Nigeria. Furthermore, the proliferation of Sandcrete masonry block-making factories in most Nigerian cities and the steady decline in the quality of majority of the produced Sandcrete masonry blocks have necessitated this study. Therefore, the aim of this study is to conduct a city-wide quality assessment of Sandcrete masonry blocks produced in Lagos, Ibadan and Abeokuta metropolitan-cities in South-western Nigeria; through the experimental determination and comparative analysis of the Compressive-strengths and Water-absorption coefficients with the stipulated industry standard values.

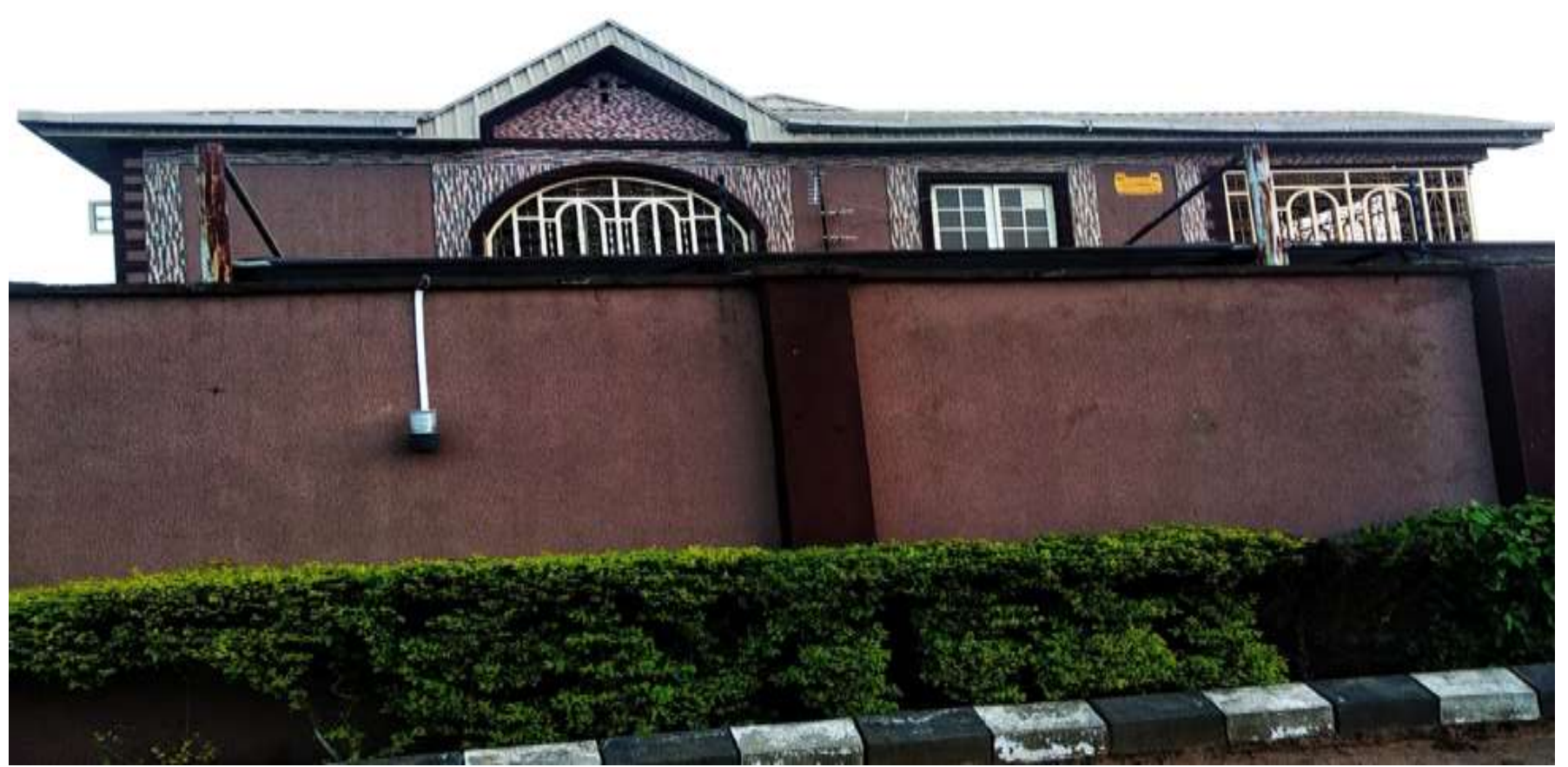

Figure 5: A Building and its Perimeter-fence constructed using Sandcrete masonry blocks and plastered with mortar; with landscaping (kerb stones and flowers etc.). Moreover, while the exterior finishing material of the Perimeter-fence is only paint; while the exterior finishing materials of the building are paint and ceramic-tiles 


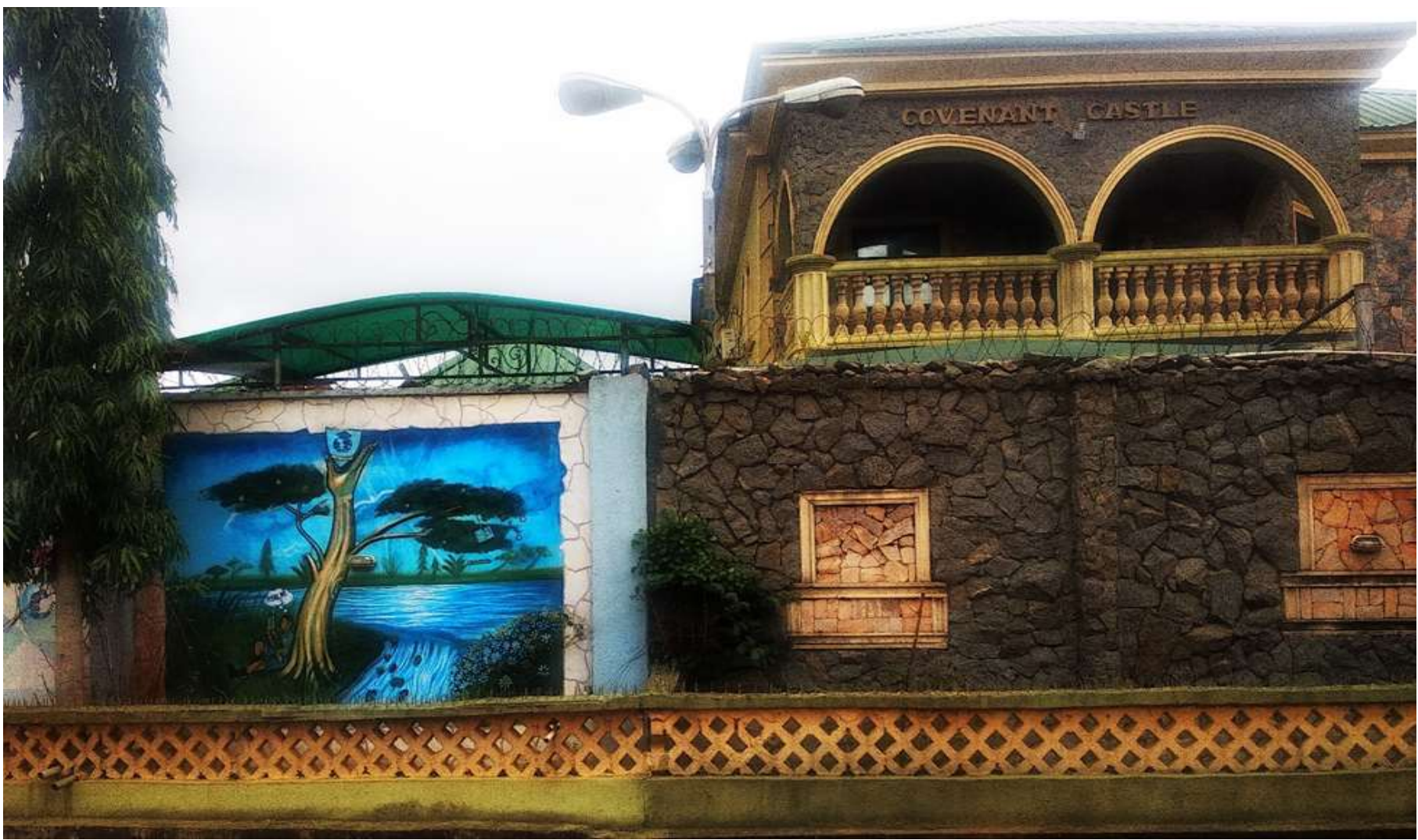

Figure 6: A Building and its Perimeter-fence constructed using Sandcrete masonry blocks and plastered with mortar. The exterior finishing of the Building and its Perimeter-fence is comprised of Painting, Painted art works, quarried Granite ('Hard core') stones and quarried Gravel stones

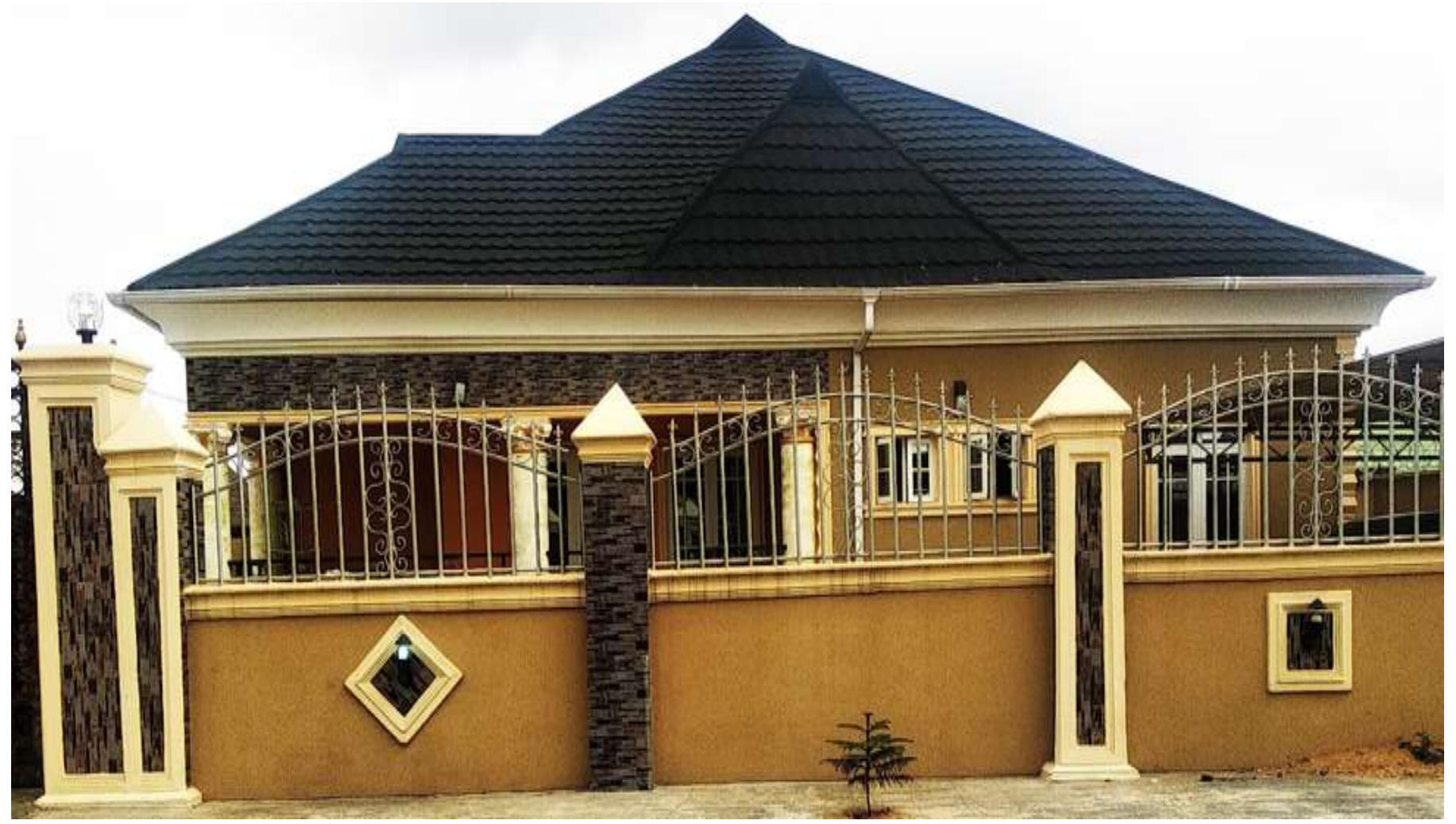

Figure 7: A Building and its Perimeter-fence constructed using Sandcrete masonry blocks and plastered with mortar. The exterior finishing of the Building and its Perimeter-fence is comprised of Painting and wall tiles 


\section{MATERIALS AND METHOD}

\subsection{The Study-area}

As could be seen in Figures 8 and 9, the study-area comprised of three metropolitan-cities ['Lagos', 'Ibadan' and 'Abeokuta'] which are also the respective capital-cities of the three states ['Lagos', 'Oyo' and 'Ogun'] with the highest Internally Generated Revenues (IGRs) and Housing-deficit Indices in South-western Nigeria. It should also be noted that, these three cities-Lagos, Ibadan and Abeokuta are among the most-populated and oldest state-capitals in the South-western geo-political zone of Nigeria; and that South-western Nigeria posits as the economic nerve-centre of Nigeria and West-Africa in general.

In each of these three (3) cities, ten (10) towns/localities with a relatively high frequency (occurrence) of multiple on-going housing construction projects (private or public) were first identified. After which ten (10) Sandcrete block-making factories sited within each of the identified towns/localities were carefully selected as being ideal for this study, on the basis of: the relative extent of patronage, scale of business activities, frequency of fresh daily production and number of customer/client referrals. Thus, a total number of three hundred (300) Block-making factories [i.e. 3 Cities * 10 Towns/Localities per City * 10 Block-making factories per Town/Locality] were selected for this study, as could be seen in Tables 1-3.

\subsection{Production Materials}

The materials (ingredients) which were used to produce the Sandcrete blocks were Cement, Fine aggregate and Mixing water.

\subsubsection{Cement:}

All the block production factories from which experimental Sandcrete block samples were collected, made use of one of four (4) commonly-used brands ['Larfarge', 'Dangote', 'Ibeto' and 'Unicem'] of ASTM type 1 Ordinary Portland Cement-which based on the visual observation of the certification labels printed on the bagging materials were products which conformed to the ISO 9001:2008, NIS 444-1:2003 and BS EN 197-1:2000 standards [2].

\subsubsection{Fine Aggregate:}

The fine aggregates used were either sun-dried sharp sand or soft sand, or disproportionate mixtures of both.

\subsubsection{Mixing Water:}

As recommended by the Standards Organization of Nigeria (SON) in its most-recently reviewed Standard Code 'NIS 87: 2007', the selected block production factories, applied potable (drinkable) water obtained from drilled water boreholes to mix the cement and sand.

\subsection{Test Samples}

The two groups of test samples were: the ' 6 " $(150 \mathrm{~mm})$-thick hollow sandcrete block group' [comprising of masonry blocks of dimensions $450 \mathrm{~mm} * 150 \mathrm{~mm} * 150 \mathrm{~mm}$ ] and the ' 9 "(225 mm)-thick hollow sandcrete block group' [comprising of masonry blocks of dimensions $450 \mathrm{~mm} * 225 \mathrm{~mm} * 225 \mathrm{~mm}$ ]. Both groups were produced by the compaction of water-moistened mixtures of the above materials in steel moulds, after which, they were sun-dried. Also, the operators/workers of the three hundred (300) selected block-production factories cured the blocks by sprinkling water on them for 24 hours after production and sun-drying for curingages ranging from 5-15 days, then, a cumulative total of nine thousand $(9,000)$ numbers of $6 "(150 \mathrm{~mm})$-thick hollow sandcrete block test-samples and another cumulative total of nine thousand (9,000) numbers of 9"(225 mm)-thick hollow sandcrete block test-samples were collected by random sampling and then, subjected to laboratory testing.

\subsection{Equipment}

The equipment used for this study included the following: Digital weighing scale, Water-curing tank and Compression-testing machine.

\subsection{Experimental Work and Procedure}

As was previously mentioned, a total of nine thousand $(9,000)$ numbers of $6 "(150 \mathrm{~mm})$-thick and another total of nine thousand $(9,000)$ numbers of 9"(225 mm)-thick Sandcrete masonry blocks were collected as test-samples from three hundred (300) Sandcrete block-making factories, which were randomly sited in thirty (30) rapidly developing towns/localities located in 'Lagos', 'Ibadan' and 'Abeokuta' cities in South-Western Nigeria. 
International Journal of Advances in Scientific Research and Engineering (ijasre), Vol 6 (8), August -2020

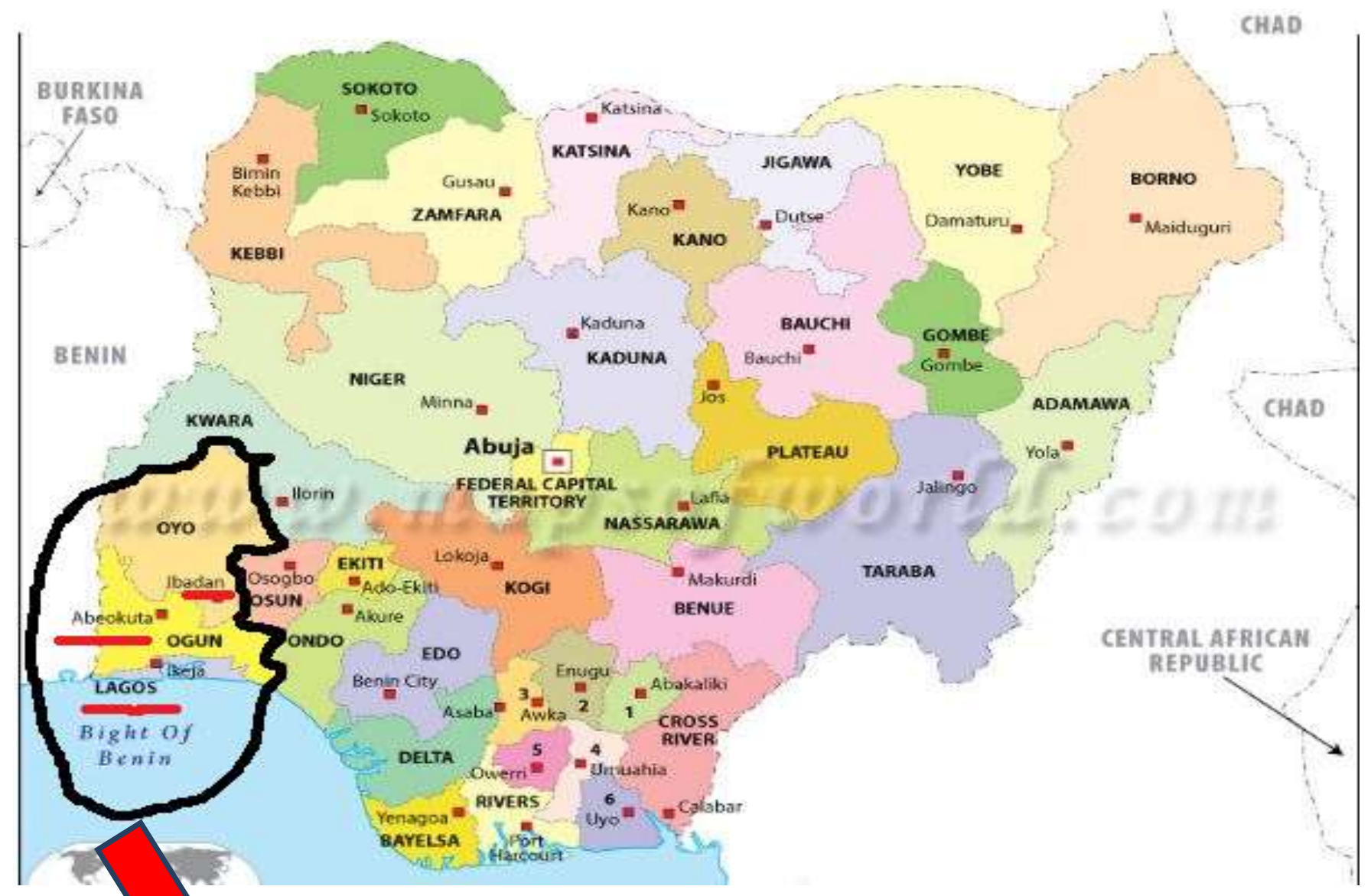

Figure 8: Map of Nigeria showing the 36 States and Capital-cities with the Federal Capital Territory (Abuja) [58]

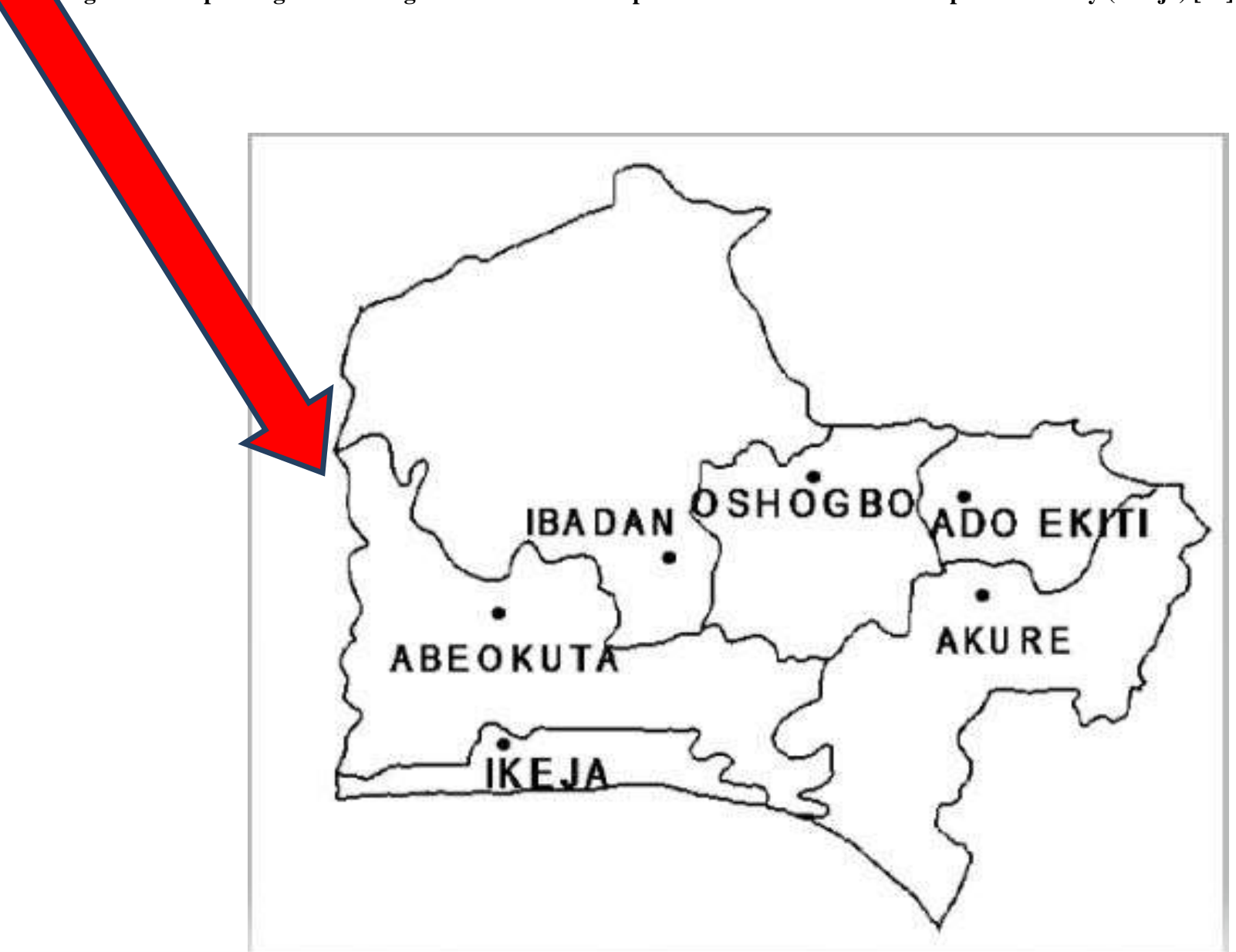

Figure 9: Map of South-west Nigeria showing Lagos (Ikeja), Ibadan and Abeokuta Cities [59], [60] 
In summary:

[3 Cities * 10 Localities per City * 10 Block-making factories per Locality * 30 Numbers of ' 6 inch-thick block test-samples']

and,

[3 Cities * 10 Localities per City * 10 Block-making factories per Locality * 30 Numbers of ' 9 inch-thick block test-samples']

Each of the ' 6 inch-thick block test-samples' and ' 9 inch-thick block test-samples' was subjected to two (2) critical Qualityevaluation tests - i.e. Compressive-strength $\left(f_{\text {block }}\right)$ test [using a compression-testing machine] and Water absorption coefficient $\left(W_{A C}\right)$ test —as recommended by the Standards Organization of Nigeria (SON), for the basic quality assessment of sandcrete blocks [13]. After which, the mean values [of ' $f_{\text {block }}$ ' and ' $W_{A C}$ '] were computed and adopted as the representative/characteristic data for each block-making factory. This was then followed by the computation of the respective mean values [of ' $f_{\text {block }}$ and ' $W_{A C}$ '] for each town/locality and their consequent adoption as the representative/characteristic data for each town/locality. Correspondingly, this [i.e. the computation of each city's overall average values from the above (already) computed average values] was also done for each of the three cities - Lagos, Ibadan and Abeokuta. Consequently, the obtained results/data were then comparatively analysed using the Standards Organization of Nigeria 'SON' NIS 87: 2007 standard specified (recommended) values to empirically evaluate the block-making/production quality of each of town/locality per city and of each city.

\title{
2.5.1. Water-absorption Coefficient $\left(W_{A C}\right) \underline{\text { Test: }}$
}

With the aid of a Digital weighing scale [which was carefully checked to ensure that its previous validation was still valid], the dry weight $\left(W_{1}\right)$ of each of the test-samples (blocks) was determined and recorded. After which they were all completely immersed in water for a duration of twenty-four (24) hours, inside the water curing tank. Also, the wet weight $\left(W_{2}\right)$ of each of the test-samples (blocks) was determined by weighing the water-immersed blocks with the same Digital weighing scale.

Thus,

'Water Absorption Coefficient' $W_{A C}=\frac{W_{2}-W_{1}}{W_{1}} * \frac{100}{1} \%$

where:

\author{
' $W_{1}$ ' is Dry weight of test-sample (block) in Newton ' $N$ ' \\ ' $W_{2}$ ' is Wet weight of test-sample(block) after being immersed in water for 24 hours in Newton ' $N$ '
}

Then, the mean values of ' $W_{A C}$ ' so obtained in each of the three city-wide study-locations were then recorded and shown in

Tables 1-3.

\subsubsection{Compressive-strength $\left(f_{\text {block }}\right)$ Test:}

Based on the Standard Organization of Nigeria's (SON) recommended Nigerian Industrial Standard 'NIS 87: 2000 code specification' for making hollow sandcrete blocks, the Compressive-strength test of each of the test-samples (blocks) was conducted as summarily explained. In order to ensure that the crushing load was uniformly distributed around the block's surface during the crushing process; smooth wooden planks were placed at the top and bottom of the test-sample (block). It was then positioned at the centre between the crushing plates of a compression testing machine, which could exert a maximum crushing force (load) of $1500 \mathrm{KN}$.

After switching-on the compression testing machine and operating it to ensure that the test-sample (block) was crushed, the maximum crushing force (load) at which failure occurred was indicated (shown) and noted. After which, it was divided by the net Cross-sectional area of the test-sample (block), to obtain the Compressive-strength expressed in ' $\mathrm{N} / \mathrm{mm}^{2}$, as is summarily shown (expressed) below.

$$
f_{\text {block }}\left(\mathrm{N} / \mathrm{mm}^{2}\right)=\frac{\text { Maximum Crushing Load during Failure }(\mathrm{N})}{\text { Net Cross-sectional Area of Block }\left(\mathrm{mm}^{2}\right)}
$$


International Journal of Advances in Scientific Research and Engineering (ijasre), Vol 6 (8), August -2020

where:

for the $6 "(150 \mathrm{~mm})$-thick hollow Sandcrete block with dimensions of $450 \mathrm{~mm} * 150 \mathrm{~mm} * 150 \mathrm{~mm}$ as shown in Figure 10 below:

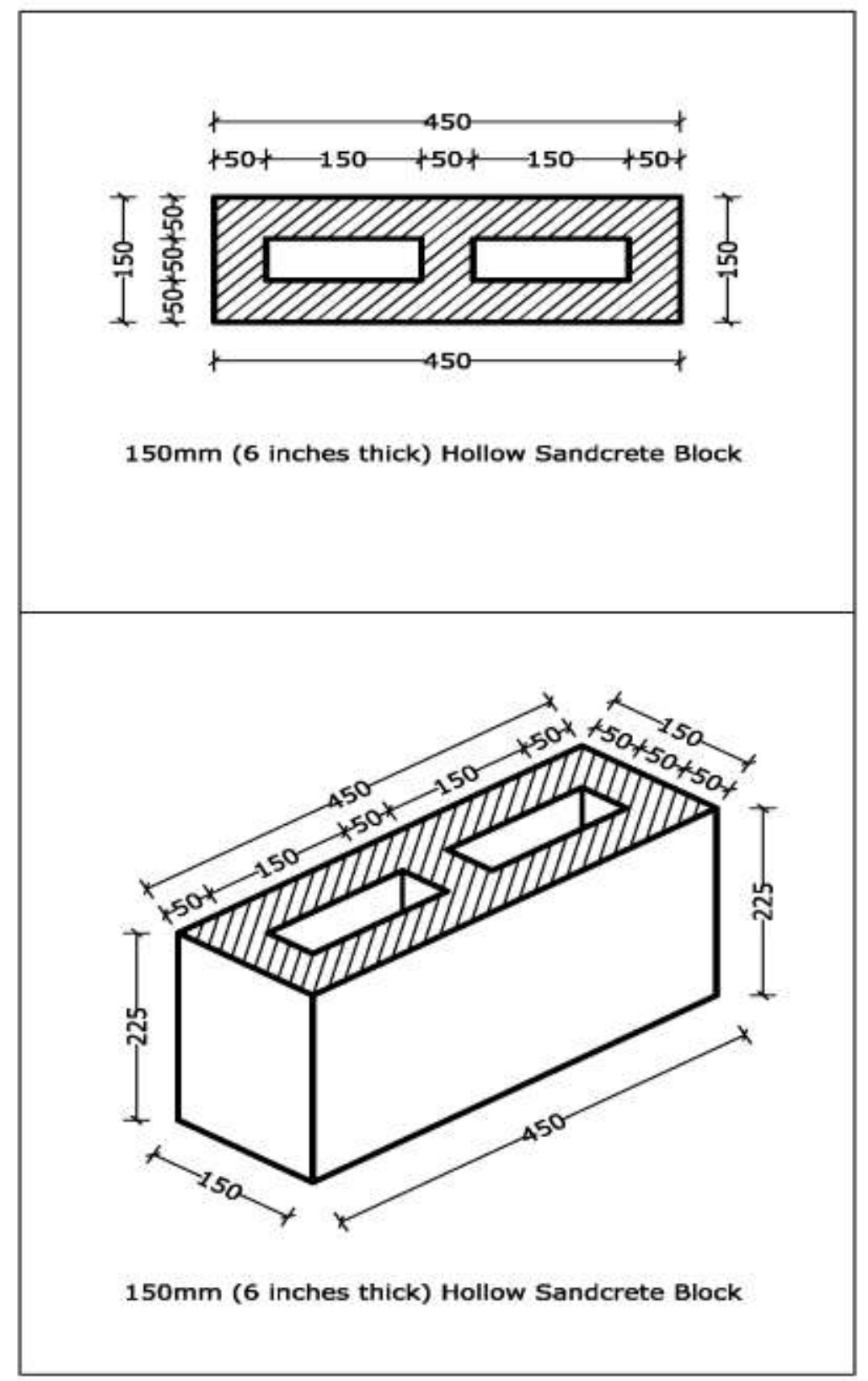

Figure 10: A Standard 6" (150mm)-thick Sandcrete Masonry Block with its dimensions

Net Cross sectional Area of Block $=$ [Gross Cross-sectional area of Block $]-[$ Sum of Areas of 2 Identical Hollow sections of Block $]$ Net Cross sectional Area of Block $=$ [Gross Cross-sectional area of Block $]-$ [Twice the Area of 1 Hollow section of Block] Net Cross sectional Area of Block $=[450 * 150]-[2(150 * 50)]$

Net Cross sectional Area of Block $=[67500]-[2(7500)]$

Net Cross sectional Area of Block $=[67500]-[15000]$

Net Cross sectional Area of Block $=52500 \mathrm{~mm}^{2}$

Then,

This first area value was substituted into 'Equation (2)' above to compute the Compressive-strength in ' $\mathrm{N} / \mathrm{mm}^{2}$, as shown in 'Equation (3)' below.

$$
f_{6^{\prime \prime b l o c k ~}}\left(\mathrm{~N} / \mathrm{mm}^{2}\right)=\frac{\text { Maximum Crushing Load during Failure }(\mathrm{N})}{52500 \mathrm{~mm}^{2}}
$$

\section{DOI: $10.31695 / \mathrm{IJASRE.2020.33856}$}


International Journal of Advances in Scientific Research and Engineering (ijasre), Vol 6 (8), August -2020

and,

for the 9"(225 mm)-thick hollow Sandcrete block with dimensions of $450 \mathrm{~mm} * 225 \mathrm{~mm} * 225 \mathrm{~mm}$ as shown in Figure 11 below:

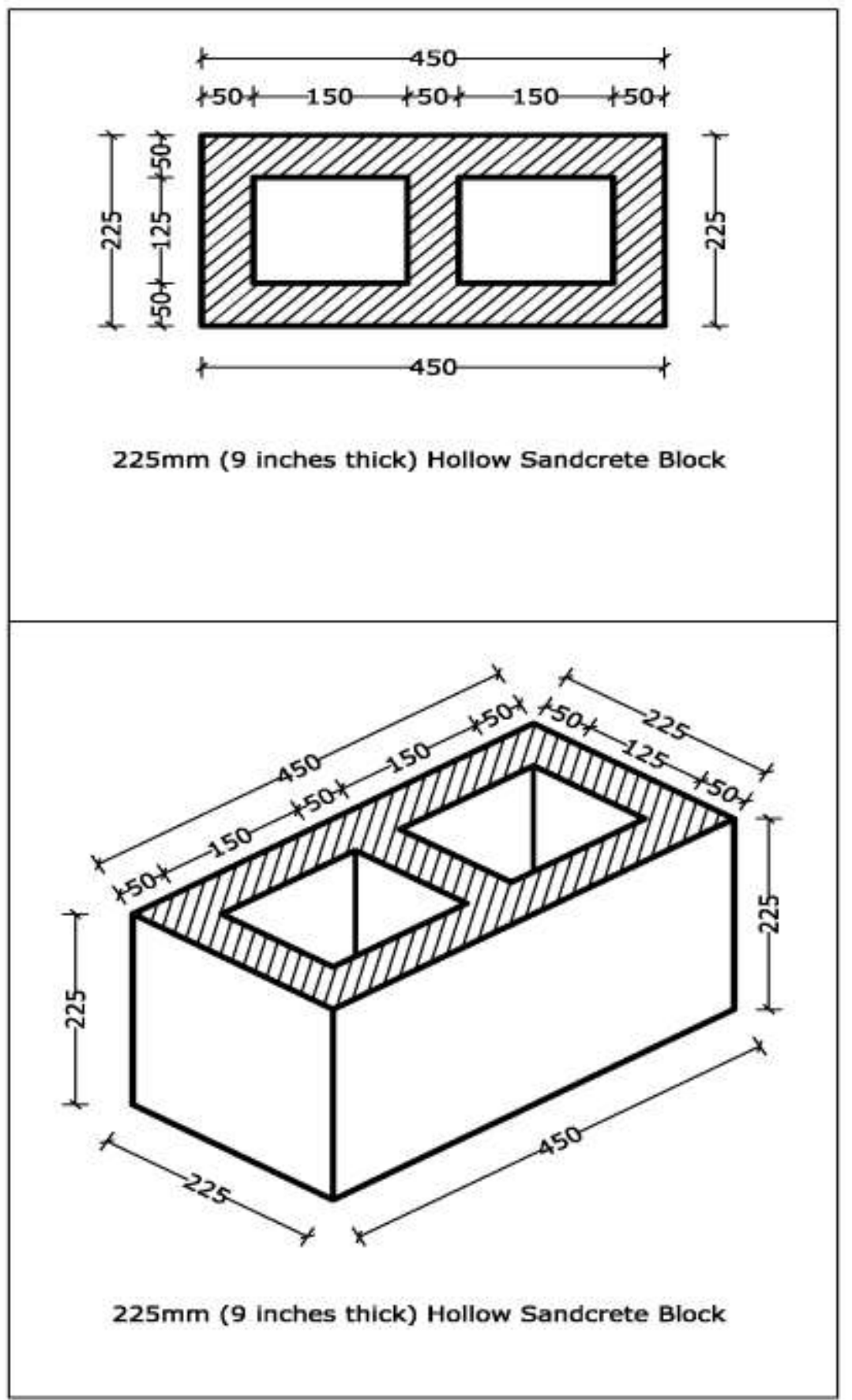

Figure 11: A Standard 9” (225mm)-thick Sandcrete Masonry Block with its dimensions

Net Cross sectional Area of Block $=$ [Gross Cross-sectional area of Block] - [Sum of Areas of 2 Identical Hollow sections of Block $]$ Net Cross sectional Area of Block $=$ [Gross Cross-sectional area of Block] - [Twice the Area of 1 Hollow section of Block] Net Cross sectional Area of Block $=[450 * 225]-[2(150 * 125)]$

Net Cross sectional Area of Block $=[101250]-[2(18750)]$

Net Cross sectional Area of Block $=[101250]-[37500]$

Net Cross sectional Area of Block $=63750 \mathrm{~mm}^{2}$

Similarly, this second area value was then substituted into 'Equation (2)' above to compute the Compressive-strength in ' $N / \mathrm{mm}^{2}$ ' as shown in 'Equation (4)' below.

$$
f_{9^{\prime \prime b l o c k}}\left(N / \mathrm{mm}^{2}\right)=\frac{\text { Maximum Crushing Load during Failure }(\mathrm{N})}{63750 \mathrm{~mm}^{2}}
$$


International Journal of Advances in Scientific Research and Engineering (ijasre), Vol 6 (8), August -2020

\subsubsection{Comparative Analysis:}

The procedure was repeated for each of the total number of eighteen thousand $(18,000)$ test-samples (Sandcrete blocks) collectively obtained at the 3 cities of the study-area; and then, the values of each parameter obtained are presented in Tables 1-3.

\section{RESULTS AND DISCUSSION}

Tables 1-3 below give a report a summarized report of the experimental results and data obtained during this city-wide study.

TABLE 1: Mean Values of Compressive-strengths and Water Absorption Coefficients of 6 Inch-thick and 9 Inch-thick Sandcrete Masonry Blocks Produced in Ten Towns/Localities in Lagos City, Lagos State, South-Western Nigeria

\begin{tabular}{|c|c|c|c|c|c|}
\hline \multirow[b]{2}{*}{ S/No. } & \multirow{2}{*}{$\begin{array}{c}\text { Town/Locality } \\
\text { of } \\
\text { Block-making } \\
\text { Factories cluster } \\
\text { in } \\
\text { LAGOS City, } \\
\text { Nigeria }\end{array}$} & \multicolumn{2}{|c|}{$\begin{array}{c}\text { 6" (150 mm)-thick } \\
\text { Sandcrete Masonry Block }\end{array}$} & \multicolumn{2}{|c|}{$\begin{array}{c}\text { 9" (225 mm)-thick } \\
\text { Sandcrete Masonry Block }\end{array}$} \\
\hline & & $\begin{array}{c}\text { Mean } \\
\text { Compressive } \\
\text { Strength } \\
\text { ' } f_{\text {block }} \text { ' } \\
\left(\mathrm{N} / \mathrm{mm}^{2}\right)\end{array}$ & $\begin{array}{c}\text { Mean } \\
\text { Water } \\
\text { Absorption } \\
\text { Coefficient } \\
\text { ' } W_{A C} \text { ' } \\
(\%)\end{array}$ & $\begin{array}{c}\text { Mean } \\
\text { Compressive } \\
\text { Strength } \\
' f_{\text {block }} \\
\left(\mathrm{N} / \mathrm{mm}^{2}\right)\end{array}$ & $\begin{array}{c}\text { Mean } \\
\text { Water } \\
\text { Absorption } \\
\text { Coefficient } \\
\text { ' } W_{A C} \text { ' } \\
\text { (\%) }\end{array}$ \\
\hline 1 & Town/Locality 1 & 1.91 & 18.03 & 1.10 & 17.21 \\
\hline 2 & Town/Locality 2 & 1.73 & 15.53 & 1.55 & 14.06 \\
\hline 3 & Town/Locality 3 & 1.81 & 17.79 & 1.61 & 17.20 \\
\hline 4 & Town/Locality 4 & 1.25 & 16.97 & 2.43 & 15.50 \\
\hline 5 & Town/Locality 5 & 1.15 & 15.37 & 1.21 & 14.76 \\
\hline 6 & Town/Locality 6 & 1.81 & 15.43 & 1.36 & 17.17 \\
\hline 7 & Town/Locality 7 & 1.87 & 16.66 & 1.79 & 14.00 \\
\hline 8 & Town/Locality 8 & 1.21 & 14.64 & 1.45 & 17.18 \\
\hline 9 & Town/Locality 9 & 2.20 & 13.49 & 1.32 & 15.48 \\
\hline 10 & Town/Locality 10 & 1.93 & 17.99 & 1.03 & 14.76 \\
\hline \multicolumn{2}{|c|}{ Average of Mean Values } & 1.69 & 16.13 & 1.49 & 15.73 \\
\hline
\end{tabular}

\subsection{Case-study 1: Sandcrete Blocks Produced in Lagos City, Nigeria}

Based on the experimental results displayed in Table 1, it could be seen that the Compressive-strength $\left(f_{\text {block }}\right)$ of the 6"-thick (150 mm-thick) and 9"-thick (225 mm-thick) Sandcrete blocks produced in Lagos city averaged at $1.69 \mathrm{~N} / \mathrm{mm}^{2}$ and $1.49 \mathrm{~N} / \mathrm{mm}^{2}$ respectively; and ranged from $1.15 \mathrm{~N} / \mathrm{mm}^{2}$ to $2.20 \mathrm{~N} / \mathrm{mm}^{2}$ and $1.03 \mathrm{~N} / \mathrm{mm}^{2}$ to $2.43 \mathrm{~N} / \mathrm{mm}^{2}$ respectively. These Compressive-strength values are below the standard values of $2.5 \mathrm{~N} / \mathrm{mm}^{2}$ and $3.5 \mathrm{~N} / \mathrm{mm}^{2}$ specified by NIS 87: 2007 standard as the minimum Compressive-strength for 6"-thick Sandcrete blocks and 9"-thick Sandcrete blocks respectively.

Also, from Table 1, it could be seen that, the Water-absorption Coefficients $\left(W_{A C}\right)$ of the 6"-thick $(150 \mathrm{~mm}$-thick) and 9"-thick (225 mm-thick) Sandcrete blocks produced in Lagos city averaged at $16.13 \%$ and $15.73 \%$ respectively; and ranged from $13.49 \%$ to $18.03 \%$ and $14.00 \%$ to $17.21 \%$ respectively. These Water Absorption Coefficients are higher the standard value of 12\% specified by NIS 87: 2007 as the maximum Water Absorption Coefficient for both 6"-thick Sandcrete blocks and 9"-thick Sandcrete blocks. 
International Journal of Advances in Scientific Research and Engineering (ijasre), Vol 6 (8), August -2020

TABLE 2: Mean Values of Compressive-strengths and Water Absorption Coefficients of 6 Inch-thick and 9 Inch-thick Sandcrete Masonry Blocks Produced in Ten Towns/Localities in Ibadan City, Oyo State, South-Western Nigeria

\begin{tabular}{|c|c|c|c|c|c|}
\hline \multirow[b]{2}{*}{ S/No. } & \multirow{2}{*}{$\begin{array}{l}\text { Town/Locality } \\
\text { of } \\
\text { Block-making } \\
\text { Factories cluster } \\
\text { in } \\
\text { IBADAN City, } \\
\text { Nigeria }\end{array}$} & \multicolumn{2}{|c|}{$\begin{array}{c}\text { 6" (150 mm)-thick } \\
\text { Sandcrete Masonry Block }\end{array}$} & \multicolumn{2}{|c|}{$\begin{array}{l}\text { 9" (225 mm)-thick } \\
\text { Sandcrete Masonry Block }\end{array}$} \\
\hline & & $\begin{array}{c}\text { Mean } \\
\text { Compressive } \\
\text { Strength } \\
\text { 'f } f_{\text {block }}^{\prime} \\
\left(\mathrm{N} / \mathrm{mm}^{2}\right)\end{array}$ & $\begin{array}{c}\text { Mean } \\
\text { Water } \\
\text { Absorption } \\
\text { Coefficient } \\
\text { ' } W_{A C}{ }^{\prime} \\
(\%) \\
\end{array}$ & $\begin{array}{c}\text { Mean } \\
\text { Compressive } \\
\text { Strength } \\
\text { 'f } f_{\text {block }}^{\prime} \\
\left(\mathrm{N} / \mathrm{mm}^{2}\right)\end{array}$ & $\begin{array}{c}\text { Mean } \\
\text { Water } \\
\text { Absorption } \\
\text { Coefficient } \\
\text { ' } W_{A C} \text { ' } \\
(\%) \\
\end{array}$ \\
\hline 1 & Town/Locality 1 & 1.53 & 18.19 & 2.47 & 17.13 \\
\hline 2 & Town/Locality 2 & 1.95 & 16.93 & 1.75 & 15.28 \\
\hline 3 & Town/Locality 3 & 1.64 & 14.98 & 1.83 & 18.15 \\
\hline 4 & Town/Locality 4 & 1.88 & 14.14 & 1.72 & 14.63 \\
\hline 5 & Town/Locality 5 & 1.57 & 13.97 & 1.96 & 18.24 \\
\hline 6 & Town/Locality 6 & 2.35 & 14.87 & 1.84 & 14.97 \\
\hline 7 & Town/Locality 7 & 1.48 & 14.29 & 1.77 & 17.40 \\
\hline 8 & Town/Locality 8 & 1.21 & 17.08 & 1.89 & 14.25 \\
\hline 9 & Town/Locality 9 & 1.92 & 17.97 & 1.66 & 17.47 \\
\hline 10 & Town/Locality 10 & 1.81 & 15.07 & 1.98 & 14.03 \\
\hline \multicolumn{2}{|c|}{ Average of Mean Values } & 1.73 & 15.75 & 1.89 & 16.16 \\
\hline
\end{tabular}

\subsection{Case-study 2: Sandcrete Blocks Produced in Ibadan City, Nigeria}

Following the trend of Lagos city, similar results were obtained at Ibadan city, as reported in Table 2, where from the following results in Table 2, it was evident that, for both the 6"-thick and 9"-thick blocks: the minimum Compressive-strengths $\left(f_{\text {block }}\right)$ were $1.21 \mathrm{~N} / \mathrm{mm}^{2}$ and $1.66 \mathrm{~N} / \mathrm{mm}^{2}$, the average Compressive-strengths were $1.73 \mathrm{~N} / \mathrm{mm}^{2}$ and $1.89 \mathrm{~N} / \mathrm{mm}^{2}$, and the maximum Compressive-strengths were $2.35 \mathrm{~N} / \mathrm{mm}^{2}$ and $2.47 \mathrm{~N} / \mathrm{mm}^{2}$ respectively. Obviously, the NIS 87:2007 specified minimum Compressive-strength values of $2.5 \mathrm{~N} / \mathrm{mm}^{2}$ for 6 "-thick $\left(150 \mathrm{~mm}\right.$-thick) Sandcrete blocks and $3.5 \mathrm{~N} / \mathrm{mm}^{2}$ for 9 "-thick (225 mm-thick) Sandcrete blocks, are higher than all of the above reported values of Compressive-strength of Sandcrete blocks produced in Ibadan city, Nigeria.

In addition, from Table 2, it is evident that, the NIS 87: 2007 specified maximum Water Absorption Coefficient $\left(W_{A C}\right)$ of $12 \%$ is lower than the ten (10) mean values of $W_{A C}$ that were separately obtained for both the 6"-thick (150 mm-thick) [Minimum $W_{A C}=13.97 \%$; Maximum $W_{A C}=18.19 \%$ ] and as well as the larger-sized 9"-thick (225 mm-thick) [Minimum $W_{A C}=14.03 \%$; Maximum $W_{A C}=18.24 \%$ ] Sandcrete blocks which were produced in Ibadan city. These therefore suggest that, virtually all the tested Sandcrete blocks are of low quality in terms of Compressive-strength and Water absorption coefficient considerations. 
International Journal of Advances in Scientific Research and Engineering (ijasre), Vol 6 (8), August -2020

TABLE 3: Mean Values of Compressive-strengths and Water Absorption Coefficients of 6 Inch-thick and 9 Inch-thick Sandcrete Masonry Blocks Produced in Ten Towns/Localities in Abeokuta City, Ogun State, South-Western Nigeria

\begin{tabular}{|c|c|c|c|c|c|}
\hline \multirow[b]{2}{*}{ S/No. } & \multirow{2}{*}{$\begin{array}{c}\text { Town/Locality } \\
\text { of } \\
\text { Block-making } \\
\text { Factories cluster } \\
\text { in } \\
\text { ABEOKUTA City, } \\
\text { Nigeria }\end{array}$} & \multicolumn{2}{|c|}{$\begin{array}{c}\text { 6" (150 mm)-thick } \\
\text { Sandcrete Masonry Block }\end{array}$} & \multicolumn{2}{|c|}{$\begin{array}{c}\text { 9" (225 mm)-thick } \\
\text { Sandcrete Masonry Block }\end{array}$} \\
\hline & & $\begin{array}{c}\text { Mean } \\
\text { Compressive } \\
\text { Strength } \\
\text { 'f } f_{\text {block }}^{\prime} \\
\left(\mathrm{N} / \mathrm{mm}^{2}\right)\end{array}$ & $\begin{array}{c}\text { Mean } \\
\text { Water } \\
\text { Absorption } \\
\text { Coefficient } \\
\text { ' } W_{A C} \text { ' } \\
(\%)\end{array}$ & $\begin{array}{c}\text { Mean } \\
\text { Compressive } \\
\text { Strength } \\
\text { 'f } f_{\text {block }}^{\prime} \\
\left(\mathrm{N} / \mathrm{mm}^{2}\right)\end{array}$ & $\begin{array}{c}\text { Mean } \\
\text { Water } \\
\text { Absorption } \\
\text { Coefficient } \\
\text { ' } W_{A C} \text { ' } \\
\text { (\%) }\end{array}$ \\
\hline 1 & Town/Locality 1 & 2.16 & 15.89 & 2.75 & 13.2 \\
\hline 2 & Town/Locality 2 & 2.67 & 11.37 & 3.24 & 12.8 \\
\hline 3 & Town/Locality 3 & 2.24 & 12.64 & 3.51 & 11.6 \\
\hline 4 & Town/Locality 4 & 2.57 & 11.82 & 3.14 & 13.1 \\
\hline 5 & Town/Locality 5 & 2.19 & 13.43 & 3.32 & 11.6 \\
\hline 6 & Town/Locality 6 & 2.28 & 13.61 & 3.11 & 12.5 \\
\hline 7 & Town/Locality 7 & 2.46 & 14.97 & 3.54 & 10.7 \\
\hline 8 & Town/Locality 8 & 2.60 & 11.65 & 3.50 & 11.1 \\
\hline 9 & Town/Locality 9 & 2.02 & 12.91 & 3.52 & 10.9 \\
\hline 10 & Town/Locality 10 & 2.32 & 16.22 & 3.52 & 10.8 \\
\hline \multicolumn{2}{|c|}{ Average of Mean Values } & 2.35 & 13.45 & 3.32 & 11.83 \\
\hline
\end{tabular}

\subsection{Case-study 3: Sandcrete Blocks Produced in Abeokuta City, Nigeria}

Abeokuta city's Sandcrete blocks gave better results than Lagos city and Ibadan city—in terms of both Compressive-strength and Water Absorption Coefficient. This is because, as is captured in Table 3: the Minimum, Average and Maximum Compressivestrengths $\left(f_{\text {block }}\right)$ of the 6 "-thick (150 mm-thick) Sandcrete blocks produced in Abeokuta city stood at $2.02 \mathrm{~N} / \mathrm{mm}^{2}, 2.35 \mathrm{~N} / \mathrm{mm}^{2}$ , and $2.67 \mathrm{~N} / \mathrm{mm}^{2}$ respectively. While, for the 9"-thick (225 mm-thick) Sandcrete blocks produced in Abeokuta city, some of values of the tested parameters were: $2.75 \mathrm{~N} / \mathrm{mm}^{2}$ [as Minimum Compressive-strength], $3.32 \mathrm{~N} / \mathrm{mm}^{2}$ [as Average Compressivestrength], and 3.54N/ $\mathrm{mm}^{2}$ [as Maximum Compressive-strength].

Furthermore, it is should be noted from Table 3 that, three (3) out of the total number of ten (10) tested 6"-thick Sandcrete block test-sample groups were of standard quality, i.e. were actually appropriate (adequate) strength-wise - since they had Compressivestrength $\left(f_{\text {block }}\right)$ values that were either equal to, or higher than the NIS 87: 2007 specified minimal value of $2.5 \mathrm{~N} / \mathrm{mm}^{2}$ for building construction applications. On the other hand, five (5) out of the total number of ten (10) tested 9"-thick Sandcrete block test-sample groups were of standard quality, i.e. were appropriate actually appropriate (adequate) strength-wise — since they had Compressive-strength values $\left(f_{\text {block }}\right)$ that were either equal to, or higher than the NIS 87: 2007 specified minimal value of $3.5 \mathrm{~N} / \mathrm{mm}^{2}$ for building construction applications. 
Moreover, Table 3 shows that: three (3) out of the total number of ten (10) tested 6"-thick Sandcrete block test-sample groups and six (6) out of the total number of ten (10) tested 9"-thick Sandcrete block test-sample groups gave satisfactory results for Water Absorption Coefficient $\left(W_{A C}\right)$ testing with respect to the NIS 87: 2007 specified maximum value of 12\% for both 6"-thick Sandcrete blocks [range of $W_{A C}=11.37-16.22 \%$ ] and 9"-thick Sandcrete blocks [range of $W_{A C}=10.7-13.2 \%$ ] .

\section{CONCLUSION}

Based on the results obtained from the Compressive-strength and Water Absorption tests as presented in Tables 1-3, it is evident that, majority of the tested [6"-thick and 9"-thick] Sandcrete masonry blocks [produced in the visited (investigated) Sandcrete block-making factories located in Lagos, Ibadan and Abeokuta cities in Southern-western Nigeria]; failed to conform to the NIS 87: 2007 Standard specified minimum Compressive-strengths of: $2.5 \mathrm{~N} / \mathrm{mm}^{2}$; and the NIS 87: 2007 Standard specified maximum Water Absorption Coefficient of $12 \%$ for [both 6"-thick and 9"-thick ] Sandcrete masonry blocks.

Furthermore, these proven case-studies of predominant non-conformity of Sandcrete block properties with the NIS 87: 2007 Standard requirements, summarily proves that, there is the overwhelming use of substandard (low quality) Sandcrete blocks for construction of buildings - which may have contributed to the numerous cases of building collapse and structural failure in the South-western Nigerian cities of Lagos, Ibadan and Abeokuta.

Now, this non-conformity of majority of the tested Sandcrete blocks to the NIS 87: 2007 Standard can be attributed to a number of reasons including:

a) Ignorance and quackery-i.e. the lack of awareness of the existence of relevant industry standards' requirements for Sandcrete block quality assessment, such as the "NIS 87: 2007"

b) Inexperience/Incompetence - which includes the use of low-quality sand, the adoption of poor (wrong) Sand-cement mix ratio; following unrecommended block-making procedure(s) [i.e. using wrong production methods/techniques]; and carrying-out inadequate/improper curing

c) Greed-i.e. the insatiable desire to maximize profit, at the expense of quality-which is mainly a function of compressive-strength and water absorption coefficient of the sandcrete block etc.

\section{RECOMMENDATIONS}

In order to reduce the frequency of Building collapse occurrence/Structural failures which have been proven to partly caused by the use of low quality Sandcrete block for the construction of buildings, the following are recommended:

a) The Nigerian government through its relevant statutory, regulatory and professional bodies/agencies/institutions such as NBRRI (Nigerian Building and Road Research Institute), SON (Standards Organization of Nigeria), CORBON (Council of Registered Builders of Nigeria), NIOB (Nigerian Institution of Building), COREN (Council for the Regulation of Engineering in Nigeria), and NSE (The Nigerian Society of Engineers) etc; should standardize the process of Sandcrete Block-making/production in the country.

b) The Government [through the aforementioned bodies/agencies/institutions] should exercise continuous technical oversight (monitoring \& support) over Sandcrete block-making factories in the country, so as to ensure the production of high-quality Sandcrete blocks across the country.

c) Sandcrete block-making factories should engage the services of experiences professionals/experts.

d) There should be proper supervision of the artisans and unskilled/inexperienced staff/persons who work in Sandcrete block-making factories.

e) The managers of Sandcrete block-making factories should ensure the continuous training and retraining of their technical staff/workers by competent and registered professionals/experts in the field.

\section{ACKNOWLEDGMENT}

The authors will be forever grateful to GOD almighty for his infinite grace, mercy and favour before, during and after the course of this research work. Also, worthy of mention are the management and staff members of Hafalix (Nigeria) Limited, Port Harcourt \& Lagos Offices, Nigeria; Redsav (Nigeria) Limited, Lagos, Nigeria; and Cintojon Company (Nigeria) Limited, Ota \& Lagos Offices, Nigeria - there is no doubt that your individual and collective determinations, tireless efforts and relentless commitments have become vital building blocks in the historic account of this successfully executed research project-that is critically important to the construction sectors of many developing countries and others. Kudos!!! 


\section{REFERENCES}

[1] O. Ibhadode, A. A. Adekunle, S. O. Banjo and O. D. Atakpu, "Thermo-physical, Electrical and Mechanical Characterizations of Normal and Special Concretes: A Holistic-Empirical Investigation for Pre-qualification and QualityControl of Concrete", Journal of Physics: Conference Series, IOP Publishing, 2019, 1378042100 , Article number 042100. DOI: 10.1088/1742-6596/1378/4/042100

[2] O. Ibhadode, T. Bello, A. E. Asuquo, F. W. Idris, F. A. Okougha, I. I. Umanah, M. C. Ugonna, and D. N. Nwaigwe, "Comparative-study of Compressive-strengths and Densities of Concrete Produced with Different Brands of Ordinary Portland Cement in Nigeria", International Journal of Science and Engineering Research, vol. 8, No. 9, September 2017, pp.1260-1275.

[3] E. A. Pauline, I. Osagie, A. A. Razaq and S. O. Moses, "Experimental Determination of Drinking Water Quality in Abeokuta Metropolis, South-western Nigeria”, International Jouirnal of Scientific Research and Engineering, vol. 4, No. 12, December 2018, pp.241-256. DOI: 10.31695/IJASRE.2018.33035

[4] A. S. Ogbiye, I. T. Tenebe, P. C. Emenike, I. D. Diwa, D. O. Omole, M. Omeje, U. B. Ngene, O. K. Oyekweredike, O. Ibhadode, "Preliminary Assessment of the Current Pollution Status of river Atuwara, Nigeria, within an Industrial Site: A Bivariate Approach", WIT Transactions on Ecology and the Environment, River Basin Management, vol. 234, 2019, pp.209-219. http://library.witpress.com

[5] Wikipedia, "Sandcrete", Wikipedia online publication, https://en.wikipedia.org/wiki/Sandcrete

[6] M. Abdullahi, "Compressive Strength of Sandcrete Blocks in Bosso and Shiroro Areas of Minna, Nigeria", AU J. T., vol. 9, October 2005, pp.126-132.

[7] J. O. Afolanyan, C. Arum and C. M. Arum, "Characterization of the Compressive Strength of Sandcrete Blocks in Ondo State, Nigeria", Journal of Civil Engineering Research and Practice, vol. 5, April 2008, pp.15-28.

[8] A. B. Sholanke, O. I. Fagbenle, A. P. Aderonmu and M. A. Ajagbe, "Sandcrete Block and Brick Production in Nigeria Prospects and Challenges", IIARD International Journal of Environmental Research, vol. 1, No. 4, 2015, pp.1-17. www.iiardonline.org

[9] B. K. Baiden and M. M. Tuuli, "Impact of Quality Control Practices in Sandcrete Blocks Production", Journal of architectural Engineering, vol. 10, June 2004, pp.53-60. DOI: 10.1061/(ASCE)1076-0431

[10] R. Barry, "The Construction of Buildings", Cross-by Lockwood, London, England, Vol. 1, 1969, pp.50-94.

[11] A. A. Olufisayo, "Strength Properties of Commercially produces Sandcrete Blocks in Ado Ekiti, Akure and Ile Ife Nigeria", International Journal of Engineering Science Invention, vol. 2, August 2013, pp.25-34.

[12] D. E. Ewa and J. O. Ukpata, "Investigation of the Compressive Strengths of Commercial Sandcrete Blocks in Calabar Nigeria", International Journal of Engineering and Technology, vol. 3, April 2013, pp.477-482.

[13] NIS 87:2007. Nigerian Industrial Standard: Standard for Sandcrete Blocks, Standard Organization of Nigeria (SON), Lagos, Nigeria.

[14] N. Jackson and R. K. Dhir, Civil Engineering Materials, Macmillan Press Limited, London, England, 1996.

[15] A. Vallenger, Construction Industry Handbook, Medical and Technical Publishers, Aylesbury, England, 1979.

[16] A. A. Hamza and S. Yusuf, Comparing the Compressive Strength of Six- and Nine-Inches Hand-moulded Sandcrete Blocks, Journal of Engineering and Applied Sciences, vol. 3, pp.584-591.

[17] T. Y. Tsado, S. M. Auta, O. James and S. B. Ahmed "Quality Assurance of Hollow Sandcrete Block: A Case-study of Hollow Sandcrete Blocks Industries in Minna, Niger State, Nigeria”, 1st International Engineering Conference, Federal University of Technology-Minna, October 2015, pp.518-532.

[18] G. D. Taylor, "Materials in Construction - Principles, Practice and Performance", Pearson Publishers, 2002 , www.pearsoned.co.uk ISBN-13: 978-0-582-36934-4

[19] S. Jibrin, S. Emmanuel, J. Ismaila, O. Ibhadode, B. Y. Alfred, F. I. Waziri and E. Sunny, "Use of Waste Plastics in Cementbased Composite for Lightweight Concrete Production”, International Journal of Research in engineering Technology, vol. 2, No. 5, 2017, pp.44-54.

[20] A. S. Ogunro, F. I. Apeh, O. C. Nwannenna and O. Ibhadode, "Recycling of Waste Glass for Clay used in Ceramic Tile Production”, American Journal of Engineering Research, vol. 7, No. 8, 2018, pp.272-278.

[21] A. Adekunle, E.S. Ekandem, K. E. Ibe, G. N. Ananso and E. B. Mondigha, "Analysis of thermal and electrical properties of Laterite, clay and sand samples and their effects on inhabited buildings in Ota, Ogun state, Nigeria”, Vol.6, No. 2, 2014, pp.391-412

[22] O. Ibhadode, I. T. Tenebe, P. C. Emenike, O. S. Adesina, A. F. Okougha and F. O. Aitanke, "Assessment of Noise-levels of Generator-sets in Seven Cities of South-Southern Nigeria”, African Journal of Science, Technology, Innovation and Development, vol. 10, No. 2, 2018, pp.125-135. DOI: 10.1080/20421338.2017.1400711

[23] O. Ibhadode, O. S. Oyedepo, A. S. Ogunro, J. Azeta, S. O. Banjo, I. I. Umanah, E. S. Apeh and A. R. Ayoola “An Experimental-assessment of Human Exposure-levels to Aircraft Noise-hazards in the Neighbouring- environments of four 
Nigerian Airports”, IOP Conf. Ser.: Mater. Sci. Eng., 413 (2018) 012080, 2018, Article ～Number: ０12080, DOI: 10.1088/1757-899X/413/1/012080

[24] O. Ibhadode, A. Adekunle, Y. K. Abimiku and N. M. Umeobika, "Noise-level Characterization of Portable Electricpower Generators in North-Central Nigeria: A Brand-by-Brand Comparative-study”, International Journal Engineering Research and Advanced Technology, vol. 5, No. 4, 2019, pp.44-58. DOI: 10.31695/IJERAT.2019.3427

[25] O. Ibhadode, P. Ibhadode, A. F. Okougha, I. I. Umanah, F. O. Aitanke and S. A. B. Fiyebo, "Hazards Assessment Analyses of Fossil-fuel Generators: Holistic-study of Human Experiences and Perceptions in South-Southern Nigeria", Journal of Sustainable Development Studies, vol. 9, No. 2, 2016, pp.153-242.

[26] J. Azeta, F. Ishola, T. Akinpelu, J. O. Dirisu, I. P. Okokpujie and O. Ibhadode, "Performance Evaluation of Developed Mathematical Models of Hot Air Balloon for Drone Application”, Procedia Manufacturing, Elsevier, Science Direct, vol. 35, 2019, pp.1073-1078. DOI: 10.1016/j.promfg.2019.06.059

[27] A. Adekunle and A. Gbenga-Ilori, "Minimizing Interference in Ultra-Dense Femtocell Networks Using Graph-Based Frequency Reuse Technique", FUOYE Journal of Engineering and Technology, 2020.

[28] O. Ibhadode, A. Adekunle, C. O. Nwafor and I. I. Umanah, "Interference Mitigation Among Indoor Phone Subscribers in LTE Based Heterogeneous Networks Using Fast Response Frequency Reuse Technique", Phys.: Conf. Ser. 1378 (2019) 032019, 2019, Article Number: 032019, DOI: 10.1088/1742-6596/1378/3/032019

[29] O. Ibhadode, A. A. Adekunle, J. Azeta and Y. K. Abimiku, "An Investigation of the Influence of Femtocells Network on a Small Size Indoor Environment Using ITU-R and WINNER II Path Loss Models”, J. Phys.:Conf. Ser. 1378 (2019) 032020, 2019, Article Number: 0302020, DOI: 10.1088/1742-6596/1378/3/032020

[30] A. Adekunle, G. O. Asaolu, K. Adiji and U. A. Kasheem, "Improvement of Channel Capacity in a Multiple Input Multiple Output LTE Radio System for GSM-Users Using Ideal Power Distribution Technique", International Journal of Scientific Research and Engineering, Vol.5, No. 9, September 2019, DOI: http://doi.org/10.31695/IJASRE.2019.33494

[31] A. Adekunle, Y. K. Abimiku, N. M. Umeobika and E. E. Ameh, "Radio wave detection using cost 231-Hata model for wireless network planning: A Case-study of Senate building environs of University of Lagos, Nigeria", International Journal of Scientific Research and Engineering, Vol.4, No. 12, December 2018, DOI: http://doi.org/10.31695/IJASRE.2018.32992

[32] A. Adekunle, K. E. Ibe, M. E. Kpanaki, I. I. Umanah, C. O. Nwafor and N. Essang, "Evaluating the effects of radiation from cell towers and high-tension power lines on inhabitants of buildings in Ota, Ogun state", 2015, Journal of Sustainable Development Studies, Vol. 3, No. 1, 2015, pp.1-21

[33] A. Adekunle, A. K. Adewale, O. A. Olaifa and S. N. B. Ukoh, "Statistical Study on Types, Causes, Effects and Remedies of Corrupt Practices in Construction Industries in Nigeria", International Journal of Advances in Scientific Research and Engineering, Vol. 5, No. 4, April 2019, DOI: http://doi.org/10.31695/IJASRE.2019.33493 )

[34] A. Adekunle, I. I. Umanah, A. K. Adewale and C. C. Egege, "Analytical study of casualties in the construction industry in Nigeria with a view to provide remedial measures: case study of Lagos state", International Journal of Advances in Scientific Research and Engineering, Vol. 4, No. 8, August 2018, DOI: http://doi.org/10.31695/IJERAT.2018.3293

[35] E. S. Ekandem, P. I. Daudu, R. B. Lamidi, M. O. Ayegba and A. Adekunle, "Spontaneous Settlements: Roles and Challenges to Urban Planning”, Journal of Sustainable Development Studies, Vol.6, No. 2, 2014, pp.361-390

[36] O. Agbonkhese, E.G. Agbonkhese, E. O. Aka, J. Joe-Abaya, M. Ocholi, and A. Adekunle, "Flood menace in Nigeria: impacts, remedial and management strategies", International Institute for Science, Technology and Education (IISTE) Journal, vol. 6, No. 4, 2014, pp.32-40

[37] A. Adekunle, I. I. Umanah, K. E. Ibe and R. M. Imonikosaye, "Statistical Analysis of Fire Outbreaks in Homes and Public Buildings in Nigeria: A Case Study of Lagos State", International Journal of Engineering Research and Advanced Technology, Vol.4, No. 8, August 2018, DOI: http://doi.org/10.31695/IJERAT.2018.3294)

[38] A. Adekunle, E. A. Asuquo, N. Essang, I. I. Umanah, K.E. Ibe and A. B. Alo, "Statistical analysis of electrical fire outbreaks in buildings: case study of Lagos state, Nigeria", Journal of Sustainable Development Studies, Vol. 9, No. 1, 2016, pp.76-92

[39] C. O. Nwafor, Y. Abimiku, O. Ibhadode and E. J. Annune, "Experimental Evaluation of Radiological Hazards in Ceramic Tiles Used in the Jos-South, Area of Plateau State, Nigeria", International Journal of Advances in Scientific Research and Engineering, vol. 5, No. 12, 2019, pp.1-8. DOI: 10.31695/IJASRE.2019.33571

[40] P. Ibhadode, A. P. Ibhadode, O. Ibhadode, O. M. Sosanolu, "Post-Project Environmental Impact Evaluation of Ota Industrial Housing Estate on the Localized Environment and Environs in Ogun State, Nigeria", International Journal of Engineering Research and Advanced Technology, vol. 6, No. 1, 2020, pp.9-28. DOI: 10.31695/IJERAT.2020.3597

[41] A. Adekunle, G. O. Asaolu, K. Adiji and H. A. Bamiduro, "Impacts of electrical hazards on Nigerian construction industries with a view to provide safety measures”, Journal of Sustainable Development studies, Vol. 9, No. 2, 2016, pp.267-289

[42] O. Ibhadode, O. O. Ajayi, A. A. Abioye, J. Ismaila and A. A. Adekunle, "An evaluation of classroom-illumination: a critical requirement for effective designing and construction of naturally-illuminated schools in Nigeria", Progress in Industrial Ecology - An International Journal, vol. 13, No. 4, 2019, pp.342-372. DOI: 10.1504/PIE.2019.102849 
[43] O. Ibhadode, F. A. Okougha, C. O. Nwafor and N. Essang “An Experimental-study on Ventilation of Public Schools in Akure, Oshogbo and Ado-ekiti Cities in South-western Nigeria", IOSR Journal of Mechanical and Civil Engineering, vol. 14, No. 5, 2017, pp.34-43. DOI: 10.9790/1684-1405013443

[44] S. O. Banjo, B. O. Bolaji, O. O. Ajayi, B. P. Olufemi, O. Ibhadode and A. O. Onokwai, "Performance enhancement using appropriate mass charge of R600a in a developed domestic refrigerator", IOP Conf. Ser.: Earth Environ. Sci., 331 (2019) 012025, Article Number: 012025, DOI: 10.1088/1755-1315/331/1/012025

[45] S. O. Banjo, B. O. Bolaji, O. Ibhadode, O. S. I. Fayomi, O. B. Fakehinde, P. S. Olayiwola, S. O. Oyedepo and N. E. Udoye, "Experimental analysis of the performance characteristic of an eco-friendly HC600a as a retrofitting refrigerant in a thermal system", J. Phys.: Conf. Ser. 1378 (2019) 042033, Article Number: 042033, DOI: 1088/1742-6596/1378/4/042033

[46] S. Adesina, D. A. Agunbiade and O. Ibhadode, "Adaptive Models for Tail of Distributions", International Journal of Statistics and Economics, vol. 20, No. 2, pp.123-134.

[47] A. Adekunle, D. N. Nwaigwe, N. Essang and P. O. Samuel, "Application of road transportation system to generateelectricity via road humps in Lagos State Nigeria", International Journal of Advances in Scientific Research and Engineering, Vol. 5, No. 4, April 2019, DOI: http://doi.org/10.31695/IJASRE.2019.32993

[48] A. Adekunle, Y. K. Abimiku, C. O. Nwafor, D. N. Nwaigwe and O. Agbonkhese, "High Voltage Transformers and Electromagnetic Emissions", International Institute for Science, Technology and Education (IISTE) Journal, Vol. 46, 2015, pp.16-25

[49] M. N. Anosike and A. A. Oyebade, "Sandcrete Blocks and Quality Management in Nigeria Building Industry", Journal of Engineering, Project, and Production Management, vol. 2, No. 1, 2012, pp.37-46.

[50] U. Akeem and G. Umar, "Quality Assurance of Hollow Sandcrete Blocks Produced by Block-moulding Factories in Gombe Metropolis", Journal of Science, Technology \& Education vol. 2, No. 1, 2013, pp.61-65

[51] G. L. Oyekan and O. M. Kamiyo, "Effects of Granite fines on Structural and Hygrothermal properties of Sandcrete Blocks", Journal of Engineering and Applied Sciences vol. 3, No. 9, 2009, pp.737-741

[52] D. O. Onwuka, N. N. Osadebe and C. E. Okere, "Structural Characteristics of Sandcrete Blocks Produced in Southeast Nigeria", Journal of Innovative Research in Engineering and Sciences, vol. 4, No. 3, 2013, pp.483-490

[53] S. S. Omopariola, "An Assessment of the Compressive-strength of Solid blocks in Idiroko area of Nigeria", Research Journal in Engineering and applied Science, vol.3, No. 1, pp.38-46.

[54] J. I. Arimanwa, M. C. Arimanwa, C. E. Okere and C. T. G. Awodiji, “Assessment of the Quality of Sandcrete Blocks in Use in Owerri Imo State, South-East Nigeria”, International Journal of Engineering and Innovative Technology, vol. 3, No. 10, 2014, pp.196-206

[55] E. O. Aladeloba, J. O. Okosoto and A. Akerele, "Assessment of Standardization of Sandcrete Blocks Production in Lagos: Case-study of Alimosho Local Government Area, Lagos Nigeria”, International Journal of Development Research, vol. 5, No. 2, 2015, pp.3428-3434

[56] A. Yusuf, H.O. Aminulai, A. Abdullahi, B. Alhaji, and A.I. Alalade, "Dimensional Compliance and Compressive-strength of Sandcrete Hollow Blocks Produced in Minna Metropolis", 2nd International Engineering Conference, Federal University of Technology-Minna, October 2017, pp.1-6.

[57] A. Omoregie, "Impact of Vibration Time on Compressive Strength of Hardened Sandcrete Building Blocks", Buildings, vol. 2, No. 2, May 2012, pp.153-172. DOI: 10.3390/buildings2020153

[58] Map of Nigeria showing the 36 States and Capitals with the Federal Capital Territory, Accessed online 9th January 2020, at https://www.mapsofworld.com/nigeria/nigeria-political-map.html

[59] K. Aderogba, F. Oderinde and H. Bakare, "Spatial assessment of fresh water supply in Southwest Nigeria", Journal of Geography and Regional Planning, vol. 5, No. 1, 2011, pp.6-13

[60] Map of Nigeria showing the 36 States and Capitals with the Federal Capital Territory, Accessed online 9th January 2020, at https://www.un.org/Depts/Cartographic/map/profile/nigeria.pdf 